УДК 351.85.1

https://doi.org/10.52058/2708-7530-2021-9(15)-120-132

Кудлай Ірина Володимирівна старший викладач кафедри «Міжнародних відносин та права», Державний університет «Одеська політехніка», пр. Шевченко, 1, м. Одеса, 65044, тел.: (050) 175-71-56, e-mail: kiv@op.edu.ua, https://orcid.org/0000-0002-6154-5245

Бабіна Валентина Олександрівна кандидат політ. наук, доц. кафедри «Міжнародних відносин та права», Державний університет «Одеська політехніка», пр. Шевченко, 1, м. Одеса, 65044, тел.: (067) 716-73-05, e-mail: ona2009@ukr.net, https://orcid.org/0000-0003-2796-5024

Моісесва Тетяна Миколаївна кандидат історичних наук, доцент каф. «Міжнародних відносин та права», Державний університет «Одеська політехніка», пр. Шевченко, 1, м. Одеса, 65044, тел.: (067) 951-44-52, е-mail: m.tatyana.n.33@gmail.com, https://orcid.org/0000-0001-7129-6046

\title{
ПОЛІТИЧНА КУЛЬТУРА СУЧАСНОЇ УКРАЇНИ: ВЗАЕМОДІЯ КУЛЬТУРИ ТА ВЛАДИ
}

Анотація. В процесі історичного розвитку взаємодія політики і культури може проявлятися як взаємодія політичних, соціальних і культурних процесів, притому проявлятися по-різному в залежності від конкретних умов кожної країни.

Сьогодні українське суспільство перебуває на етапі трансформації своєї політичної системи. У статті звертається увага на особливості політичної культури сучасного української суспільства, досліджується взаємозв'язок культури та влади, виявляються шляхи вдосконалення представників влади через зміни у політичній культурі суспільства, значимість концепту політичної культури. Політична культура нового суспільства, яка формується в незалежній Україні, мусить бути культурою злагоди, громадянського миру, пошани до свобод і прав людини.

У статті розглядаються проблеми взаємовідносин влади і культури, вплив влади на культуру і вплив культури на владу. Особливу увагу приділено проблемам взаємодії політичних і культурних процесів, детерміновані культурної різнорідністю. Аналізуються дві моделі взаємодії політики і культури на цивілізаційному рівні: революційна і еволюційна.

Політичні та соціальні процеси можуть передувати культурним. I навпаки, культурні процеси можуть випереджати політичні. Взаємодія культури і політики детермінуються культурною різнорідністю. Різниця культур - це відмінність 
способів сприйняття дійсності, способів її оцінки та як наслідок - способу дій.

Людська природа така, що ми бачимо світ через свої культурні відтінки. Між рядків наших культурних законів заховано несвідоме упередження, яке заважає нам об'єктивно розглядати інші культури. Наші судження про людей з інших культур завжди будуть пофарбовані системою поглядів, в якій ми виросли.

Проблема виникає, коли ми відчуваємо, що наші культурні звички, цінності та уявлення перевершують цінності інших людей. Це може сильно вплинути на наші ділові відносини.

Ключові слова: влада, людина, суспільство, держава, культура, норма, особистість, політична культура, державна влада, трансформація суспільства, мистецтво, політика, діяльність, цивілізація.

Kudlai Iryna Volodymyrivna Senior lecturer of the department "International Relations and Law", State University "Odessa Polytechnic", Shevchenko Ave., 1, Odessa, 65044, tel.: (050) 175-71-56, e-mail: kiv@op.edu.ua https://orcid.org/00000002-6154-5245

Babina Valentyna Oleksandrivna Candidate of Political Science, Associate Professor of the Department "International Relations and Law", State University "Odessa Polytechnic", Shevchenko Ave., 1, Odessa, 65044, tel.: (067) 716-73-05, email: ona2009@ukr.net, https://orcid.org/0000-0003-2796-5024

Moiseeva Tetyana Mykolayivna Candidate of Historical Sciences, Associate Professor of the department "International Relations and Law", State University "Odessa Polytechnic", Shevchenko Ave.,1, Odessa, 65044, tel.: (067) 951-44-52, email: m.tatyana.n.33@gmail.com, https://orcid.org/0000-0001-7129-6046,

\section{POLITICAL CULTURE OF MODERN UKRAINE: CULTURE AND AUTHORITY INTERACTION}

Abstract. In the process of historical development, the interaction of politics and culture can manifest itself as the interaction of political, social and cultural processes, and manifest itself in different ways depending on the specific conditions of each country.

Today, Ukrainian society is at the stage of transformation of its political system. The article draws attention to the peculiarities of the political culture of modern Ukrainian society, explores the relationship between culture and government, identifies ways to improve government officials through changes in the political culture of society, the importance of the concept of political culture. The political culture of the new society that is being formed in independent Ukraine must be a culture of harmony, civil peace, and respect for freedoms and human rights.

The article considers the problems of the relationship between power and culture, the influence of power on culture and the influence of culture on power. Particular 
attention is paid to the problems of interaction of political and cultural processes, determined by cultural diversity. Two models of interaction between politics and culture at the level of civilization are analyzed: revolutionary and evolutionary.

Political and social processes may precede cultural ones. Conversely, cultural processes can outpace political ones. The interaction of culture and politics is determined by cultural diversity. The difference of cultures is the difference between the ways of perceiving reality, the ways of evaluating it and, as a consequence, the way of acting.

Human nature is such that we see the world through our cultural nuances. There is an unconscious prejudice between the lines of our cultural laws that prevents us from looking at other cultures objectively. Our judgments about people from other cultures will always be colored by the system of views in which we grew up.

The problem arises when we feel that our cultural habits, values and ideas are superior to other people's values. This can greatly affect our business relationships.

Keywords: power, man, society, state, culture, norm, personality, political culture, state power, transformation of society, art, politics, activity, civilization.

Постановка проблеми. Умови, в яких ми живемо, створюються для нас політиками. Хочемо ми цього чи не хочемо, але політика в будь-якому випадку вторгається в наше життя.

Влада присутня в будь-якій культурі, починаючи з «міфологічних» часів до наших днів. Саме категорія політичної культури розглядається як одна 3 ключових у процесі вивчення та прогнозування політичних процесів у конкретному суспільстві. Проблема формування і розвитку політичної культури особистості, як частини більш загального поняття «політична культура», набуває дедалі більшої гостроти. Коли ми говоримо про формування політичної культури, то маємо на увазі процес формування культури на грунті сучасного політичного досвіду українського народу, процес, що поєднує стихійні й організовані чинники.

Кожне суспільство має свою конфігурацію політичної культури. Це залежить від його історії, соціально-класової структури, типу й характеру політичної системи, економічних основ та інших обставин. Це поняття нерозривно пов'язане 3 поняттями демократії та громадянського суспільства. Процеси формування i розвитку політичної культури в сучасній Україні пов'язані, насамперед, 3 особливостями державного розвитку, типу соціально-політичних, економічних відносин i політичного досвіду, тобто вони носять конкретно-історичний характер. Становлення української політичної культури прийнято розглядати як складову процесу національно-визвольної боротьби українського народу проти різноманітних форм економічного і політичного тиску з боку держав, до складу яких входили в різний час різні частини України. Фундаментальною основою всієї української культури $є$ народна культура, i на іiі основі поступово розвивалося професійне мистецтво, література і наука. Справжніми творцями i 
носіями культури були широкі верстви суспільства - селяни, козаки, ремісники. Велике місце зайняв фольклор, народні традиції, які додали українській культурі особливого шарму і колориту.

Українська культура може пишатися своєю оригінальною i давньою системою освіти, яка досягла свого апогею в козацьку епоху, забезпечувала майже повну грамотність населення і давню традицію книжкового справи. В результаті була створена серія класичних шедеврів в області друку, архітектури, літератури і значного прогресу в науці.

Українська культура глибоко вкоренилася в давніх традиціях.

Звернемо увагу на те, що своєрідність української культури також визначалося впливом географічних умов, історичного шляху, а також взаємодією з іншими етнічними культурами. Оскільки Україна географічно розташована між Європою і Азією, велика частина їі культури демонструє як східні, так і західні впливи. Сьогодні країна в деякому сенсі культурно розділена: західні регіони мають більш сильний європейський вплив, а східні регіони - слов'янський.

Аналіз останніх досліджень і публікацій. Можна виділити основні підходи зарубіжних і вітчизняних соціологів до вивчення сутності даної категорії.

Так, усвідомленням влади і іiі дослідженням займалися багато відомих мислителі: Макіавеллі, Гоббс, М. Вебер та ін., кожен з яких вносив щось нове у вчення про владу. Макіавеллі обгрунтував сутність і соціальну природу політичної влади, Гоббс вивчав державну владу індивідуума, волею якого підкоряються всі інші члени суспільства; М. Вебер вважав, що влада $\epsilon$ відносинами панування людей над людьми, а політика являє собою прагнення до участі у владі, щоб проводити власну волю навіть всупереч опору більшості, всупереч опору ззовні.

В традиціях, закладених Е. Дюркгеймом, культура розглядається як система ідеалів, цінностей, норм, зразків поведінки, які регулюють відносини між людьми. У. Томас розумів під культурою матеріальні і соціальні цінності

будь-якої групи (інститути, звичаї, установки, поведінкові реакції). У. Самнер, А. Келлер писали, що сукупність пристосувань людини до його життєвим умовам є культура, або цивілізація. М. Вебер підкреслював, що культура - це модель раціональної поведінки. К. Г. Юнг мав на увазі під нею форми звичайної поведінки. Низка науковців (Вербицька П., Манакін В., Трейгер Г., Холл Е., Шайгородський Ю. та інші) стверджують, що моделі поведінки людини формуються в процесі виховання у певному соціокультурному середовищі.

Однією із найважливіших складових зазначеної моделі є комунікація, яка здійснюється відповідно до норм та правил, прийнятих у конкретному соціумі. Порушення цих норм і правил часто призводить до непорозуміння і може стати перешкодою на шляху до успішного комунікативного процесу.

Дослідженням міжкультурної комунікативної компетентності займалися: T. Бутенко, I. Данченко, Н. Завініченко, А. Касаткіна, I. Козубовської, 
А. Краєвська, С. Макаренко, В. Назаренко, Н. Тимофєєва, А. Хом'як, В. Черевко та ін. Л. Г. Почебут приділяла велику увагу цим питанням розробила теорію міжкультурної комунікативної компетентності як психологічної передумови конструктивної взаємодії представників влади та різних культур.

Серед класичних робіт зарубіжних досліджень комунікативної компетентності з точки зору теорії комунікації і культурології слід відзначити праці: L. Bachman, M. Canale, N. Chomsky, K. Foss, O. Argie, J. Koester, D. O'Hair, A. Palmer, G. Rickheit, H. Widdowson, C. Sabee і ін. Також в західній літературі дуже ретельно ці питання вивчали такі вчені, як Г. Хофстед, Ф. Тромпенаарс, С. Ронен, Р. Мід, Е. Шейн, М . Портер, Ф. Лютенс.

Мета статті - методологічні дослідження в області взаємодії культури i влади та сучасний вплив крос культурної компетентності на сучасні події, яке дозволяє побачити істотні зміни, що відбуваються в даному науковому напрямку в сучасний період.

Викладання основного матеріалу. $Є$ два шляхи взаємодії культури i політики на цивілізаційному рівні:

1) еволюційний і 2) революційний (за В. Д. Поповим). Перший шлях пов'язаний із взаємодією культури і політики всередині цивілізації. Це відбувається через природні зміни власної культури, а державно-політична оболонка так чи інакше до них пристосовується. Але можливий і другий шлях, коли політичні зміни передують культурним, коли державно-політична сфера ініціює культурні зміни. Зазвичай в цьому випадку первинні імпульси змін виходять 3 інших культур (цивілізацій).

Отже. відмінною особливістю сучасного етапу розвитку людського суспільства $є$ тісний зв'язок культурних i політичних процесів. В області культури, як і в інших сферах суспільного життя, політика спрямовує соціальну діяльність людей. У свою чергу в культура має великий вплив на політику своїми уявленнями про світ, цінностями, зразками поведінки.

На сучасному етапі ці процеси пов'язані, насамперед, 3 відновленням i розвитком демократичних традицій життя суспільства в політичній культурі України і з подоланням залишків тоталітарної свідомості, яка, з точки зору ряду дослідників, була притаманна всім народам, що проживають на території колишнього Радянського Союзу. Така свідомість і культура характеризувалися затвердженням авторитету партійно-державних структур i масовим, іноді необмеженим, ідеологічним і політичним насильством. Створення сучасної, ефективної системи державної влади $є$ важливим чинником виходу українського суспільства 3 політичної кризи, що має забезпечити становлення України як високо розвинутої, правової, цивілізованої, європейської держави з високим рівнем життя, соціальної стабільності, культури, демократії. [1] Сучасна демократична держава, якою прагне стати Україна, немислима без участі елементів політичної культури, тому першочерговим завданням, що стоїть на шляху змін в українському суспільстві $є$ формування активної громадянської 
позиції. Процес становлення політичної культури - складова національного відродження України, це складний системний процес, який демонструє зв'язок між зростанням національної, історичної свідомості та політичної культури.

Розвиток політичної культури - природно-історичний процес, який знаходиться під впливом різних історичних, соціальних, економічних, політичних факторів, деякі 3 них носять стихійний характер і тому особливо важливо звертати увагу на цілі та завдання, які ставить перед собою українське суспільство, саме загальний національний ідеал - демократична правова соціальна держава - $\epsilon$ тією дороговказною зіркою, яка забезпечує процеси подолання фрагментарності в української політичної свідомості та української політичної культурі. Агентами формування і розвитку політичної культури в демократичній державі крім самої держави повинні виступати ЗМI, система освіти, громадські та політичні організації, церква. Саме ці інститути забезпечують трансформації в українській політичній культурі, які ускладнюються специфікою геополітичного положення України між Заходом i Сходом, і труднощами історичних доль українського народу.

Людей вчать вести себе їх сім'ї, заклади освіти та образ мислення, а також суспільство, в якому вони живуть. Етична поведінка також відноситься до поведінки, яка $є$ загальноприйнятою в певній культурі. Деякі види поведінки $є$ загальноприйнятими - наприклад, люди не повинні завдавати фізичної шкоди іншим людям. Інші дії менш зрозумілі, наприклад, дискримінація за віком, раси, статі або етнічної приналежності.

Культура впливає на те, як місцеві цінності впливають на глобальну ділову етику. Існують відмінності й в тому, яке значення в культурах надають конкретним етичним нормам поведінки. Однак з огляду на вплив західної думки на світ за останні кілька століть, стало прийнято, що всі люди в будь-якій країні і будь-якого походження рівні і повинні мати рівні можливості.

Об'єктом політики є влада. Влада $є$ однією 3 фундаментальних засад політичного розвитку суспільства. Вона має правовий, економічний, духовноідеологічний характер, існує всюди, де наявні будь-які стійкі об'єднання людей (сім'я, плем'я, держава), тісно пов'язана 3 політичною сферою, $є$ засобом здійснення i способом утвердження певної політики. Влада $\epsilon$ необхідним регулятором життєдіяльності суспільства, забезпечує його розвиток, єдність, керованість, слугує важливим фактором організованості i впорядкованості соціуму.

Держава представляє суспільство і забезпечує його політичну і економічну спільність і єдність. Вона виконує основний обсяг управлінської діяльності найважливіших сфер суспільного і економічного життя. Управлінські рішення реалізуються за допомогою особливого державного механізму. Приймаючи правові та нормативні акти, держава може дозволяти, забороняти або обмежувати діяльність політичних партій, організацій та рухів.

В сучасній Україні відбувається процес переплаву елементів різних 
політичних роз'єднаних регіональних субкультур в єдину поліструктурну одиницю - політичну культуру українського народу, яка повинна характеризуватися саме як громадянська політична культура, бо саме вона забезпечить стабільний розвиток українського соціуму на шляху утвердження демократії та створення правової соціальної держави 3 розвиненим громадянським суспільством. Питання державного розвитку в Україні сьогодні безпосередньо залежать від рівня політичної культури різних верств населення, суспільства в цілому. [12]

Культура і влада сутнісно пов'язані між собою. На цю обставину важливо звернути увагу ще й тому, що їх нерідко протиставляти. Тим часом наскільки очевидно, що влада як така неможлива поза і без культури як такої, настільки вірно і зворотне: культура як соціальний феномен неможлива без і поза владою.

Влада $\epsilon$ необхідною умовою культури. Культура виростає з комунікації, але влада $\epsilon$ те, що робить можливою комунікацію як Конституційний феномен соціуму. Культура в своїй підставі $є$ сукупність норм життєдіяльності, тобто поведінка. Влада по суті своїй також не що інше, як санкціоноване встановлення системної сукупності норм життєдіяльності як взаємодії.

Ключова, сполучна ланка тут - поняття і явище норми, конкретний зміст якої і визначається культурою. I культура, і влада встановлюють кордони, відокремлюють нормальне від ненормального. Культура породжує, а влада закріплює соціальні форми. За своєю функціональною роллю культура задає або створює зразки продуктивної, комунікативної діяльності індивіда в якості цінностей. Влада - забезпечує прийняття індивідом даних цінностей як обов'язкових у процесі взаємодії з іншими індивідами.

Необхідний зв'язок культури і влади показує не тільки те, що влада завжди спирається на культурний ресурс, але саме те, що без цієї опори вона неможлива, так як стає беззмістовною, втрачає необхідні ціннісні підстави, бо вона не виробляє норми, а лише санкціонує їх. Саме тому «боротьба за культуру» завжди була боротьбою за владу, а політична революція завжди поєднувалася 3 культурною.

Формування політичної свідомості, заснованого на науковому знанні, придбання масами досвіду політичної поведінки і політичної участі, політична соціалізація на основі демократичних цінностей призведуть до поступового подолання фрагментарності політичної свідомості і політичної культури $\mathrm{i}$ дозволять позбутися від негативних елементів патріархального типу політичної культури. [15]

Виходячи з вище викладеного, велике значення має формування та розвиток політичної культури в Україні.

У сучасному цивілізованому суспільстві політика здійснюється для людей i через людей. Яку значну роль не відігравали б соціальні групи, масові суспільні рухи, політичні партії, іiі головним суб'єктом виступає особистість, бо самі ці групи, рухи, партії та інші громадські і політичні організації складаються 3 
реальних особистостей. Тільки через взаємодію їх інтересів та волі визначається зміст і спрямування політичного процесу, всього політичного життя суспільства. Активна участь особистості в політичному житті суспільства має багатопланове значення.

По-перше, через таку участь створюються умови для більш повного розкриття всіх можливостей людини, для його творчого самовираження, що становить необхідну передумову найбільш ефективного вирішення суспільних завдань. Якісне перетворення всіх сторін життя припускає всіляку інтенсифікацію людського чинника, активна і свідома участь в цьому процесі широких народних мас. Але поза демократією, довірою і гласністю стають Неможливі ані творчість, ані усвідомлена активність, ані зацікавлена участь.

По-друге, загальний розвиток людини як суб'єкта політики є важливою умовою тісного зв'язку політичних інститутів з громадянським суспільством, контролю за діяльністю політико-управлінських структур з боку народу, засобом протидії діяльного апарату управління, відділень функцій управління від суспільства.

По-третє, через розвиток демократії суспільство задовольняє потребу своїх членів брати участь в управлінні справами держави.

Політика та культура переплітаються на багатьох рівнях, проникають $\mathrm{i}$ впливають одна на одну, і складність цих переплетінь заслуговує на нашу увагу та ретельний аналіз.

Реформи 90-х рр. дали зразки сліпого копіювання досвіду інших народів, пріоритету політики над економікою, причому такої політики, за якої чітко видно корисливі інтереси самих політиків. Стало очевидним, що невиправдані очікування, які пов'язують 3 ілюзією необмежених можливостей управління суспільством, породжують вкотре в історії людства зайву самовпевненість, що завдає суспільству величезної шкоди. Виявлення основних тенденцій суспільного розвитку - процес складний в силу багатогранності цього явища.

Звернемо увагу, що у ХX ст. як ніколи раніше виявив себе величезний інноваційний потенціал культури, здатної докорінно змінювати життя людей. Розвиток культури будь-якого народу і будь-якої країни в сучасному світі не може відбуватися поза рамками міжнародної співпраці. Міжнародна культурна співпраця як принцип культурної політики повинна сприяти взаєморозумінню народів, створенню у їх відносинах атмосфери поваги, довір'я, діалогу і миру. Міжнародна культурна співпраця повинна базуватися на повазі гідності і цінності кожної культури, на відмові від спроб встановлення будь-яких форм нерівності, підкорення або заміни однієї культури іншою, на рівновазі в культурних обмінах. Складною проблемою сучасної світової культури є індустрія культури та іiі продукція - масова культура.

Саме в культурі, яка фактично охоплюе всю повноту життя сучасної людини, формуються його уявлення про світ і самому собі, саме через культуру йому пропонуються і вселяються форми поведінки, стереотипи мислення, 
життєві ідеали та цінності. У культурній свідомості здійснюється і пошук оптимального соціального устрою суспільства, проектування утопій і антиутопій як моделей бажаного, або можливого, в силу логічного розвитку тенденцій, стану суспільного устрою. I тому культура, здатна виступати як відносно самостійний компонент соціальної регуляції, стає об'єктом пильної уваги з боку керівників глобалізаційного проекту, які прагнуть підключити можливості культури до формування потрібних образів і стереотипів мислення, які б допомагали зміцнити у свідомості людей уявлення про достоїнства нового глобалізаційного порядку і його цінності.

Існують такі виміри взаємозв'язків політики i мистецтва, як естетизація політики і політизація мистецтва. Перший вимір взаємодії політики і мистецтва полягає у перетворенні мистецтва на складову політичного культу. Цей процес розкривається на основі відтворення історичної еволюції мистецтва у західноєвропейському культурному просторі, що демонструє нам перехід мистецтва від ролі складової магічного та релігійного культів до застосування мистецьких творів в якості ефективних і ефектних засобів підсилення значення i впливу політичних ритуалів.

Другий суттєвий вимір співвідношення політики і мистецтва це політизація мистецтва. Тобто мистецтво само починає претендувати на політичне перетворення людини і суспільства.

Тенденції естетизації політики і політизації мистецтва, які ми розмежували, поєднуються у реальному функціонуванні мистецтва і політики, коли, 3 одного боку, мистецькі твори обрамляють і підсилюють ефективність політичних ритуалів, рухів і організацій, а з іншого боку, перебирають на себе політичні функції мобілізації і інтеграції людей, містять заклики і розробляють засоби до перетворення суспільства. Поєднання цих тенденцій демонструє процес медіатизації політики, що включає естетику і політику у єдиний мас-медійний простір.

Мистецтво завжди відгукується на різноманітні політичні або соціальні події. Відповідно, мистецький твір все частіше пов'язаний з тим, що відбувається «зараз» в момент його творення. Естетичний потенціал мистецтва лежить в основі його політичного залучення.

В широкому сенсі зараз можна говорити, що мистецтво як таке $є$ одним із способів існування політичного дискурсу або дискурсу влади. Відповідно, багато нових ідей, що до того, якими мають бути світ й суспільство, людські стосунки та відносини, як вони трансформуються й змінюються, артикулюються найперше в мистецтві та митецьких течіях, й лише потім в соціально-політичних рухах, що добре видно з розвитку мистецтва кінця XIX - початку XX ст., наприклад, поставання та розвитку авангарду.

Становлення незалежної правової демократичної держави в Україні пов'язане $з$ формуванням української політичної культури, яка за своїм змістом $\epsilon$ культурою пригнобленого суспільства, яке намагається позбутися тоталітаризму 
й розбудувати правову, демократичну державу. Це позначається на всіх структурних компонентах державного устрою і політичної системи.

Висновки. Таким чином, сучасні процеси формування демократичної політичної культури є складовою частиною національного відродження України. Існує двосторонній взаємозв'язок між зростанням національної та історичної свідомості та політичної культури народу. Національна свідомість, так само, як і національний характер, значною мірою формуються під впливом політичних відносин минулого. Тривале перебування під колоніальним гнітом послужило причиною формування у частини народу, зневіри в можливості розвитку самостійної України. Тривале панування тоталітаризму настільки деформувало уявлення про демократію, що часто виникає загроза виникнення нового тоталітаризму, поставленого вже на службу національній ідеї. Необхідний тривалий досвід успішної діяльності демократичних інститутів, щоб у національному характері утвердилися такі риси демократії, як терпимість, готовність до співпраці з людьми, які мають інші політичні та ідейні погляди, повага прав особи і меншин.

Для вирішення різноманітних питань в культурі необхідно формувати сучасну політичну культуру як необхідну складову загальної культури, яка дає можливість вибирати і створювати міцну владу, досить справедливу, наскільки це можливо в неоднорідному суспільстві, де $\epsilon$ широкий розкид інтересів і потреб соціальних груп і особистостей. I робити це потрібно одночасно, так як влада $\mathrm{i}$ культура взаємопов'язані і зумовлюють один одного.

Таким чином, взаємодія культури і політики в процесі утвердження загальнолюдських цінностей буде приймати різні форми. Цей шлях буде важким. По-новому ставить проблеми взаємодії культури і політики сучасний світ - світ небувалої інтенсивності спілкування, посилення взаємодії, обмінів в науці, культурі, інформації, а також взаємного збагачення передовими загальнолюдськими цінностями. Внаслідок конфронтаційного розвитку світу, абсолютизації класового підходу наша країна не сприйняла багато 3 того, що було вироблено людиною протягом століть. Це принципи формального права - рівності всіх перед законом, права і свободи особистості i т. п. Вони повинні знайти відповідний своєму загальнолюдському призначенню статус культурних цінностей.

Культура може стати і стає предметом конкуренції та інструментом конкурентної боротьби в умовах інтеграції культур у глобалізованому суспільстві. Культура в силу своєї природи і змісту може виступати як м'який засіб і найбільш природний шлях до налагодження об'єднання народів, інтеграції їх у цілях реалізації програми справедливого безконфліктного життя, побудованої на засадах таких культурних цінностей, як істина і добро.

\section{Лimepamypa:}

1. Архів наукових статей., стаття № 21 «Влада» частина 2: [Електронний ресурс] URL: http://ukraineweek.at.ua/publ/1/21_vlada_chastina_2/1-1-0-24 - Дата звернення: 28.08.2021

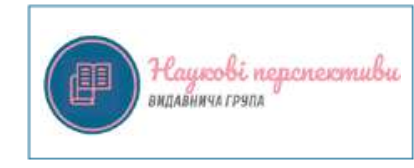


2. Бевз Т. А. Політичний процес в Україні: традиції й інновації політичної модернізації / Т. А. Бевз // Наук. зап. Ін-ту політ. і етнонац. дослідж. ім. І. Ф. Кураса НАН України. 2011. № 6. С. $25-39$.

3. Бурдяк В. I. Політична культура країн Європи в контексті інтеграційних процесів. Чернівці, 2004.

4. Буцевицький В. Проблеми політичної культури в Україні в процесі державотворення // Нова політика. 1999. № 1.

5. Давидов П. Г., Назаров Р. С. Формирование политической культуры украинской молодежи - актуальная проблема государственной политики Украины. // [Електронний ресурс] - URL: www.dipcorpus-info.at.ua. - Дата звернення: 28.08.2021

6. Дергачов О. Місце політичних партій у здійсненні влади в Україні // Політична думка. 2000. № 1 .

Кожокин Е. Политическая культура как фактор развития № 8, 2008 // [Електронний pecypc] - URL: http://sr.fondedin.ru/new/fullnews_arch_to.php?subaction=showfull\&id=1220179254 \&archive $=1220353357 \&$ start_from $=\& u c a t=14 \&$. - Дата звернення: 29.03.2021

7. Матусевич В. Політична культура: теоретико-методологічні проблеми дослідження // Соціологія: теорія, методи, маркетинг. 1998. № 4-5. С. 5-20.

8. Мельник В. В. Влада як основний засіб публічного адміністрування та механізм їх взаємодії (кандидат філософських наук, доц. каф. управління, інформаційно-аналітичної діяльності та євроінтеграції Національного педагогічного університету імені М. П. Драгоманова (Київ, Україна) // [Електронний ресурc] URL: http://www.zgia.zp.ua/gazeta/ monodrupradmin_142.pdf - Дата звернення: 28.08.2021

9. Нагорна Л. П. Політична культура українського народу. К., 1998.

10. Новікова Н. Є. Особливості формування політичної культури особистості в умовах трансформації суспільства на прикладі України // [Електронний ресурс] - URL: http://ekmair.ukma.edu.ua/bitstream/handle/123456789/10286/Novikova_Osoblyvosti_formuvannia_ politychnoi.pdf?sequence=1\&isAllowed=y - Дата звернення: 27.08.2021

11. Политическая культура современной Украины // [Електронний ресурс] - URL: https://banauka.ru/4675.html - Дата звернення: 29.08.2021

12. Поснова Т. Особливості формування політичної культури молоді // Соціальна психологія. 2004. № 6.

13. Соловьев А. И. Политология: Политическая теория, политические технологии: Учебник для студентов вузов. М.: Аспект Пресс, 2000. 559 с.

14. Суханцева В. К. Філософська освіта в контексті сучасної соціокультури. Луганськ: Вид-во СНУ ім. В. Даля, 2003. 189 с.

15. Сучасна українська політика. Аналітичні доповіді Інституту політичних i етнонаціональних досліджень ім. І. Ф. Кураса НАН України. К. : ІПіЕНД ім. І. Ф. Кураса НАН України, 2009. 448 с.

16. Формирование и развитие политической культуры в современной Украине // URL: https://all-politologija.ru/ru/formirovanie-i-razvitie-politicheskoj-kultury-v-sovremennoj-ukraine Дата звернення: 28.08.2021

17. Цимбалістий Б. Політична культура українців // Сучасність. 1994. № 4.

19. Rosenbaum W.A. Political Cultur: Basic Concept in Political Science. N.Y., Pr. publ. 1975. P. 6

20. Verba S. Conclusions: Comparative Political Culture//Pye L., Verba S. Political Culture and Political Development. Princeton, 1965. P. 516.

\section{References:}

1. Arkhiv nauchnykh statey., Stat'ya № 21 «Vlast'» chast' 2. Retrieved from: http://ukraineweek.at.ua/publ/1/21_vlada_chastina_2/1-1-0-24 
2. Bevz T. A. (2011) Politicheskiy protsess v Ukraine: traditsii $i$ innovatsii politicheskoy modernizatsii [Political process in Ukraine: traditions and innovations of political modernization] / T. A. Bevz // Nauk. zap. In-ta polet. i etnonatsional'nykh. issled. im. I. F. Kurasa NAN Ukrainy. № 6. S. 25-39. [in Ukrainian].

3. Burdyak V. I. (2004) Politicheskaya kul'tura stran Yevropy $v$ kontekste integratsionnykh protsessov [Political culture of European countries in the context of integration processes]. Chernovtsy. [in Ukrainian].

4. Butsevyts'kyy V. (1999) Problemy politychnoyi kul'tury v Ukrayini v protsesi derzhavotvorennya [Problems of political culture in Ukraine in the process of state formation] // Nova polityka.. № 1 .

5. Davydov P. G. \& Nazarov R. S. Formirovaniye politicheskoy kul'tury ukrainskoy molodezhi aktual'naya problema gosudarstvennoy politiki Ukrainy [The formation of the political culture of Ukrainian youth is an urgent problem of the state policy of Ukraine] // Retrieved from: www.dipcorpus-info.at.ua. [in Russian].

6. Derhachov O. (2000) Mistse politychnykh partiy u zdiysnenni vlady v Ukrayini [The place of political parties in the exercise of power in Ukraine] // Politychna dumka. № 1.

7. Kozhokin Ye. (2008) Politicheskaya kul'tura kak faktor razvitiya [Political culture as a factor of development] № 8 // Retrieved from: http://sr.fondedin.ru/new/fullnews_arch_to.php?Subaction $=$ showfull\&id=1220179254\&archive $=1220353357 \&$ start_from $=\& u c a t=14 \&$. [in Russian].

8. Matusevich V. (1998) Politicheskaya kul'tura: teoretiko-metodologicheskiye problemy issledovaniya [Political culture: theoretical and methodological problems of research] // Sotsiologiya: teoriya, metody, marketing. № 4, 5. [in Ukrainian].

9. Mel'nik V. V. Vlast' kak osnovnoye sredstvo publichnogo administrirovaniya i mekhanizm ikh vzaimodeystviya [Power as the main means of public administration and the mechanism of their interaction] (kandidat filosofskikh nauk, dots. Kaf. Upravleniya, informatsionno-analiticheskoy deyatel'nosti i yevrointegratsii Natsional'nogo pedagogicheskogo universiteta imeni M. P. Dragomanova (Kiyev, Ukraina) // Retrieved from: http://www.zgia.zp.ua/gazeta/ monodrupradmin_142.pdf [in Ukrainian].

10. Nagornaya L. P. (1998) Politicheskaya kul'tura ukrainskogo naroda [Political culture of the Ukrainian people]. M. [in Ukrainian].

11. Novikova N. Ye. Osobennosti formirovaniya politicheskoy kul'tury lichnosti v usloviyakh transformatsii obshchestva na primere Ukrainy [Features of the formation of political culture of the individual in the transformation of society on the example of Ukraine] // Retrieved from: http://ekmair.ukma.edu.ua/bitstream/handle/123456789/10286/Novikova_Osoblyvosti_Formuvania _politychnoi.pdf?sequence $=1 \&$ isAllowed $=\mathrm{y}$

12. Politicheskaya kul'tura sovremennoy Ukrainy [Political culture of modern Ukraine] // Retrieved from: https://banauka.ru/4675.html

13. Posnova T. (2004) Osobennosti formirovaniya politicheskoy kul'tury molodezhi [Features of formation of political culture of youth] // Sotsial'naya psikhologiya. № 6. [in Ukrainian].

14. Solov'yev A. I. (2000) Politologiya: Politicheskaya teoriya, politicheskiye tekhnologii [Political Science: Political Theory, Political Technologies]. Uchebnik dlya studentov vuzov. M .: Aspekt Press, 559 s. [in Russian].

15. Sukhantseva V. K. (2003) Filosofskoye obrazovaniye v kontekste sovremennoy sotsiokul'tury [Philosophical education in the context of modern socioculture] Lugansk: Izd-vo VNU im. V. Dalya, 2003. 189 s. [in Ukrainian].

16. Sovremennaya ukrainskaya politika [Modern Ukrainian politics]. Analiticheskiye doklady Instituta politicheskikh i etnonatsional'nykh issledovaniy im. I. F. Kurasa NAN Ukrainy. M.: IPiEND im. I. F. Kurasa NAN Ukrainy, 2009. 448 s. [in Ukrainian].

17. Formirovaniye $i$ razvitiye politicheskoy kul'tury $v$ sovremennoy Ukraine [Formation and development of political culture in modern Ukraine] // Retrieved from: https://all-politolo gija.ru/ru/formirovanie-i-razvitie-politicheskoj-+kultury-v-sovremennoj-ukraine [in Russian]. 
18. Tsimbalistyy B. (1994) Politicheskaya kul'tura Ukrainskaya [Political culture of Ukrainians] // Sovremennost'. № 4. [in Ukrainian]

19. Rosenbaum W.A.(1975) Political Cultur: Basic Concept in Political Science. N.Y., Pr. publ. P. 6 20. Verba S. (1965) Conclusions: Comparative Political Culture // Pye L., Verba S. Political Culture and Political Development. Princeton, P. 516. 